\title{
$(\boldsymbol{\theta})$
}

Juan Biondi - Eduardo Zapata

\section{Nómades electronales}

Lo que nos dicen las escrituras de los jóvenes: había que echarse a andar nuevamente

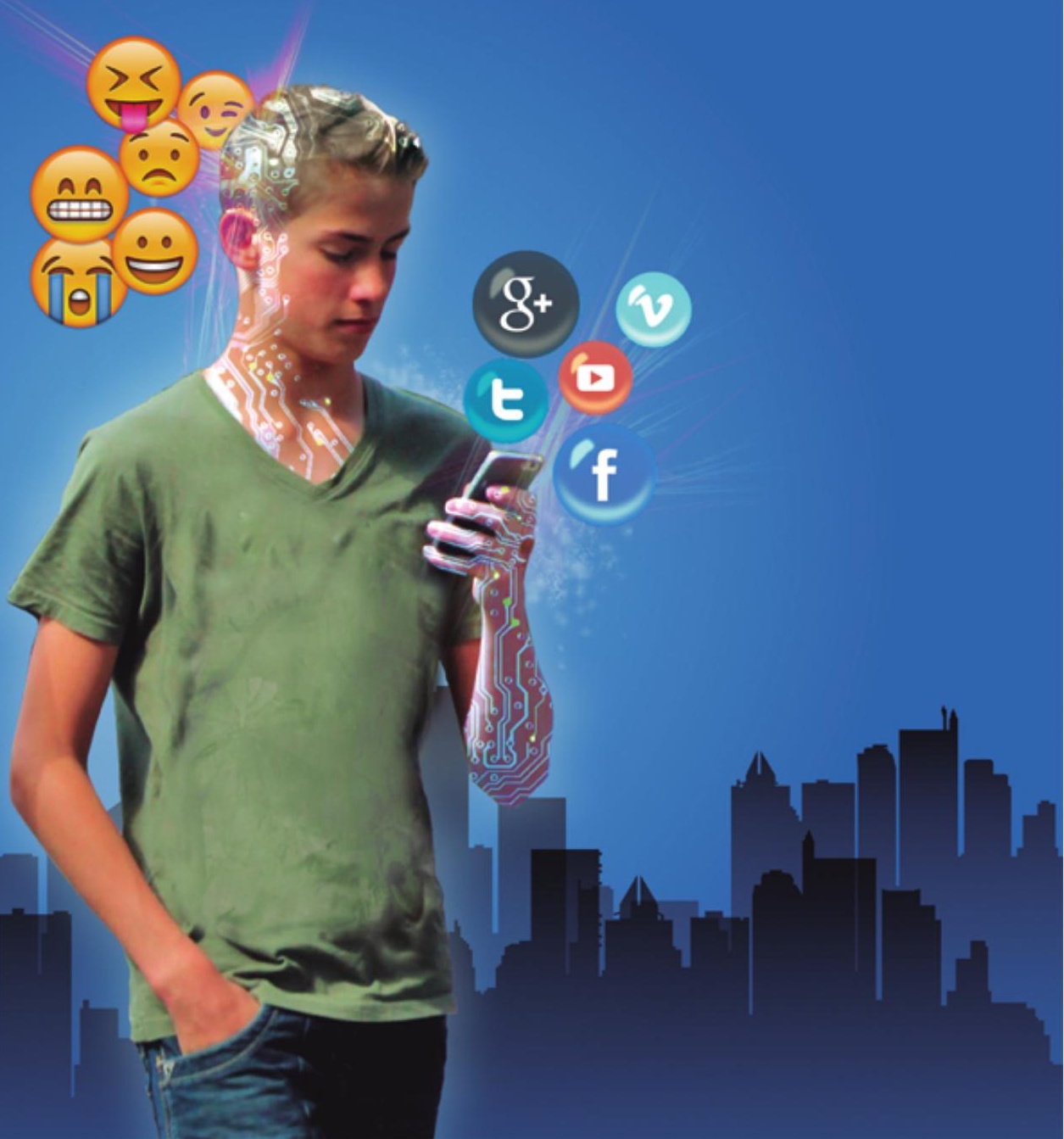


Juan Biondi - Eduardo Zapata

\section{Nómades electronales}

Lo que nos dicen las escrituras de los jóvenes:

había que echarse a andar nuevamente 
(C) Universidad Peruana de Ciencias Aplicadas (UPC)

Primera publicación: enero de 2017

Impreso en el Perú-Printed in Peru

Autores: Juan Biondi y Eduardo Zapata

Edición: Diana Félix

Corrección de estilo: Luigi Battistolo

Diseño de cubierta: Christian Castañeda

Diagramación: Diana Patrón Miñán

Editor del proyecto editorial

Universidad Peruana de Ciencias Aplicadas S. A. C.

Av. Alonso de Molina 1611, Lima 33 (Perú)

Teléf: 313-3333

www.upc.edu.pe

Primera edición: enero de 2017

Tiraje: 800 ejemplares

Este libro se terminó de imprimir en el mes de enero de 2017, en los talleres gráficos de Gráfica Biblos S. A. Jr. Morococha Nro. 152 Lima - Perú

\section{BIBLIOTECA NACIONAL DEL PERÚ \\ Centro Bibliográfico Nacional}

401.41

B55

\section{Biondi Shaw, Juan José}

Nómades electronales : lo que nos dicen las escrituras de los jóvenes : había que echarse a andar nuevamente / Juan Biondi, Eduardo Zapata.-- 1a ed.-- Lima : Universidad Peruana de Ciencias Aplicadas, 2017 (Lima : Gráfica Biblos). 136 p. : il. ; $24 \mathrm{~cm}$.

Bibliografía: p. 131-136.

D.L. $2017-01217$

ISBN 978-612-318-086-7

1. Semiótica - Aspectos sociales 2. Jóvenes - Escritura 3. Lengua española - Análisis del discurso 4. Comunicación y tecnología 5. Medios digitales 6. Lenguaje y cultura 8. Cultura - Modelos semióticos I. Zapata S., Eduardo II. Universidad Peruana de Ciencias Aplicadas III. Título

BNP: 2017-0240

Hecho el Depósito Legal en la Biblioteca Nacional del Perú nro. 2017-01217

Registro de Proyecto Editorial en la Biblioteca Nacional del Perú nro. 31501401700122

Todos los derechos reservados. Esta publicación no puede ser reproducida, ni en todo ni en parte, ni registrada en o transmitida por un sistema de recuperación de información, en ninguna forma ni por ningún medio, sea mecánico, fotoquímico, electrónico, magnético, electroóptico, por fotocopia o cualquier otro, sin el permiso previo, por escrito, de la editorial.

El contenido de este libro es responsabilidad del autor y no refleja necesariamente la opinión de los editores. 


\section{ÍNDICE}

Prólogo

Introducción

Capítulo 1. Selfie (aún borroso) de la electronalidad y sus efectos

1.1 Continuidades y rupturas

1.2 Están en otra

1.3 Prejuicios y perjuicios

1.4 Escritura electronal: patterns de producción de sentido

1.5 Algunos primeros planos

Capítulo 2. El escriba electronal

2.1 ¿Qué nos está diciendo la escritura de niños y jóvenes?

2.2 La irrupción de los emojis

2.3 Los niños no son un libro en blanco: la plasticidad del cerebro

2.4 Algunas consideraciones sobre las escrituras desde las neurociencias

Capítulo 3. Libertad, lecturas y escrituras: en búsqueda del sentido

3.1 Naturaleza y estatuto del signo a la luz de las tecnologías de la información

3.2 Filiaciones

3.3 Paso a paso, los sistemas culturales

3.4 ¿Y si nuevamente hacemos el esfuerzo de aprender a leer produciendo sentido? 


\section{PRóLOGO}

Escribo este prólogo de la obra Nómades electronales por especial pedido de mis amigos Juan Biondi y Eduardo Zapata, lingüistas y semiólogos con larga trayectoria en la formación universitaria, especialmente de los primeros años de estudios generales. Ello los ubica en una situación privilegiada para observar en las nuevas generaciones de estudiantes universitarios los diferentes modos de producción de sentido en sus comunicaciones, es decir, en la forma como codifican y decodifican los discursos.

En esta obra, los autores nos presentan estas observaciones, realizadas a través de su amplia experiencia y a partir de sus numerosas investigaciones lingüísticas y semiológicas, lo que los ha llevado a determinar que los individuos adscritos a una cultura de la oralidad y de la electronalidad tienen diferentes modos de producción de sentido en relación con la cultura de la escribalidad. Sustentan esta conclusión sobre la base del análisis de discursos respecto de los vectores de producción de sentido de los diferentes sistemas culturares. Ellos encuentran, así, mayores coincidencias en la producción de sentido entre la oralidad y la electronalidad, que difieren en lo sustancial con los vectores que otorgan sentido en el sistema cultural de la escribalidad.

Nómades electronales es un esfuerzo - desde la lingüística, la semiótica y las neurociencias- por proporcionar respuestas al significado de estos hallazgos. Los autores se plantean las siguientes preguntas sobre estas nuevas formas de codificar y de decodificar el lenguaje, a las que van dando solución en el desarrollo de la obra: «¿Qué impactos tendrían los cambios de vectores de producción de sentido en los procesos de enseñanza- aprendizaje? ¿Cuáles en la conducta personal y social? ¿Cuáles en los procesos cognitivos? ¿Estos cambios producirían cambios en el cableado y el formateo cerebral que dejarían huellas neurológicas en estos individuos electronales?». 
Susan Greenfield, neurocientífica de Oxford, y en la línea de Umberto Eco, escribió en su libro The Private Life of the Brain: «Estamos ante un cambio trascendental de la condición humana [...] en la cual se discutirán los sistemas de valores y respecto a la cual se elaborarán nuevos modelos ético-pedagógicos». El lenguaje electronal constituye una nueva lógica que regula la propia lógica del hecho social y cultural. Y esta es una evidencia que comienza a presentarse ante nuestros ojos.

En una entrevista de La Nación de Buenos Aires, Greenfield comentó: «Estamos entrando a un nuevo mundo. No diría que es aterrorizador, aunque todo lo nuevo da miedo [...] pero sí requiere que meditemos sobre él [...] no podemos atravesarlo como sonámbulos».

Los jóvenes electronales están construyendo un nuevo tipo de escritura que responde a sus propias necesidades de comunicación, las que son a su vez expresión y configuración de cambios culturales que comprometen la propia plasticidad del cerebro.

La doctora Alba Richaudeau, neuropsicóloga, afirma lo siguiente: «Las investigaciones demandan tiempo y los avances tecnológicos avanzan a una velocidad superior [...] Internet impacta en el funcionamiento cerebral [...] Nos refiere que hay ciertos estudios que dan cuenta de cómo el cerebro se está adaptando a este nuevo medio».

La lectura de Nómades electronales es, pues, un viaje apasionante realizado a través de un profundo análisis lingüístico-semiológico, con interesantes aportes desde las neurociencias, con el que podremos vivenciar los alcances y significados que estos cambios producirán en los ámbitos de la educación, la cultura, lo social, lo político, lo intelectual y, obviamente, todo aquello que concierna a la propia cognitividad y a los universos axiológicos. Estamos ante nuevas formas de concepción de la comunicación misma, y renovadas estrategias y técnicas de comunicación habrán de transitar por estos senderos.

Los usuarios de la tecnología de la información se encuentran con las exigencias propias de un mundo cambiante. Esto los coloca en una permanente búsqueda, que los obliga a navegar, explorar, desplazarse e indagar sobre nuevos sentidos. Es decir, en convertirse en nómades electronales.

\section{Luis Caravedo Reyes}

Profesor principal y exdecano de la Facultad de Medicina de la Universidad Peruana Cayetano Heredia 


\section{INTRODUCCIÓN}

Atender hechos de habla. Describir pertinencias. Trazar sentido. Anteponer sentido a interpretación: tareas de una semiótica con filiación lingüística.

Es la atención a los hechos de habla lo que nos permite comprobar que cuando nos referimos a palabra hablada y escritura fonética o electronal no estamos haciendo alusión a pasados y presentes y menos a estadios de inferioridad/superioridad. Las tecnologías de la información que se suceden en el tiempo han configurado sistemas de signos cuyas pertinencias permiten hablar de personas adscritas a la oralidad, a la escribalidad y hoy a la electronalidad.

Es la atención a los hechos de habla lo que nos permite no reducir los sistemas culturales a meras externalidades. No es el acto de hablar lo que nos hace pertenecer a la oralidad ni los actos de leer o escribir aquello que nos adscribe a la escribalidad, así como tampoco el empleo de una computadora nos hace electronales.

Es la atención a los hechos de habla, en fin, lo que nos ha permitido identificar que oralidad, escribalidad y electronalidad remiten a modos de producir sentido. Y que son estos modos -que reiteramos en este libro- los que crean imaginarios sui generis y públicos objetivos diferentes.

Cada lengua -lo sabemos- configura una visión del mundo, una manera de ser y estar en él. Pero también el hecho de que una sociedad privilegie en un tiempo y espacio dados una tecnología de la información instala en nosotros un software que nos hace producir/consumir sentido de una determinada manera. Podemos saber leer y escribir, por ejemplo, pero, si la ecología del medio social que nos rodea ha privilegiado la tecnología de la información de la palabra hablada, nuestro modo de producir sentido obedecerá a dicho entorno ecológico. 
Cuando en 1989 escribimos el libro El discurso de Sendero Luminoso: contratexto educativo, el análisis nos permitió comprender que, si bien el discurso del movimiento subversivo apelaba a estrategias de comunicación dirigidas fundamentalmente a públicos objetivo orales y semialfabetizados, ese mismo discurso no podía escapar a fuentes escribales provenientes de su ideología. Podía tratarse de grafiti, canciones o teatro popular, codificados apelando a características culturales de los públicos objetivo, pero era claro que la mente del emisor adscribía a la escribalidad.

Trabajos de campo ulteriores -de los cuales dimos cuenta en los libros Representación oral en las calles de Lima, La palabra permanente y Derribando muros- nos permitieron reafirmar la vigencia del sistema cultural de la oralidad en el Perú, la adscripción de algunos sectores a la escribalidad y la inmersión de los más jóvenes ya en el mundo de la electronalidad. No era asunto, pues, de que unos hablaban, otros escribían y otros accedían a las computadoras: era asunto de modos de producir sentidos distintos que coexistían.

Pero la atención a los hechos de habla y a las escrituras -y particularmente a las características que viene adquiriendo la escritura electronal- nos exigió preguntarnos acerca de subyacencias referidas a los modos de producir sentido. Y nos obligó a volver los ojos a las neurociencias y a preguntarnos -desde allí y desde la semiótica- acerca de la naturaleza, el estatuto y las funciones del signo lingüístico entendido como hecho semiológico. Preocupados por el sentido y teniendo claro que siempre hay un precio que pagar por cada innovación cultural.

Y ocurre que comprobamos que los diferentes modos de producir sentido en los sistemas culturales implican una profunda modificación en la naturaleza y el estatuto del signo. Como veremos con particular énfasis en el capítulo 3, lo que la ecología de los medios escribales nos había acostumbrado a considerar como inmutable por motivado, resultaba más bien ser doblemente arbitrario y, por lo tanto, susceptible al cambio en la larga duración de la humanidad. Y el cambio alcanzaba a las propias funciones lingüísticas, que habíamos creído inmutables.

Precisamente la exigencia metodológica de atender a los hechos de habla y la constatación de lo anteriormente señalado subrayan -una vez más- que la sustancia sobre la cual se sustentan las tecnologías de la información no solo afecta naturaleza, estatuto y funciones del signo, sino que reafirman la existencia de sistemas culturales entendidos como ecología de los medios.

Y he aquí que la fugacidad de la sustancia de la palabra hablada y de la palabra electrónica -frente a la permanencia sedentaria de la palabra escrita- nos asoma al fenómeno que da título a este libro. Si sedentarismo y escritura alfabética sacralizada constituyeron 
un fecundo detenerse en la larga duración de la humanidad, hoy el ser humano -a juzgar por la escritura electronal- ha retomado su andar. Y no se trata solo de la multiplicación de los viajes físicos, sino de individuos y grupos sociales que abandonan fronteras y la ya incierta zona de confort del ayer para hacer frente a los nuevos retos creados por el cambio del entorno ecológico de los medios. En este nuevo andar los individuos y los grupos sociales tienen que reinventarse permanentemente y la eterealización de la sustancia de sus signos los urge a conectarse con la realidad -hoy más clara que nunca- de la teoría de la información. Nómades. Navegantes. Buscadores permanentes de información. Una búsqueda, al parecer, sin fin. 



\section{CAPÍTULO 1}

\section{Selfie (aún borroso) de la electronalidad y sus efectos}

\subsection{Continuidades y rupturas}

«(Por la derecha aparece el cuerpo docente compuesto por cinco miembros que llevan togas y cintas en el pecho. Avanzan con grave teoría y se acomodan en la mesa verde. Pausa. Expectativa. Los viejos miran hacia atrás como esperando la llegada de alguien. Murmullos en el público: 'AAllí está don Cosme Bueno!'. Por la derecha aparecerá un hombre gordo, pequeño y calvo, cargado de gruesos libros y manuscritos. Se dirigirá sonriente hacia la tribuna y se emplazará en ella. Pausa).

COSME B.- Ilustrísimos señores profesores de la Real y Pontificia Universidad Mayor de San Marcos. (Al Duque) Excelentísimo representante de nuestro Virrey. (A Santiago) Señor. (Pausa) Henos aquí reunidos en esta Magna Asamblea para dar lectura al informe que luego de laborioso estudio he redactado sobre la Memoria presentada por Santiago de Cárdenas, pajarero, acerca de un nuevo sistema de navegación por los aires».

(Ribeyro 1966: cuadro cuarto) 
Estamos en el siglo XviII. Gobierna el Perú el virrey Manuel de Amat y Junyent. En 1542 se había creado el Virreinato del Perú, sobre la base de inmensos territorios que hoy forman parte de Argentina, Bolivia, Colombia, Chile, Ecuador, Panamá, Perú y parte de Brasil. Hacia esos tiempos y espacios nos ha trasladado Julio Ramón Ribeyro (1929-1994) con su obra teatral Santiago, el pajarero. La escena citada líneas arriba se desarrolla en la Universidad Nacional Mayor de San Marcos, la universidad más antigua de América reconocida oficialmente por la Corona española. En ese tiempo/espacio de poder absoluto, el académico Cosme Bueno informa acerca de la propuesta presentada por Santiago de Cárdenas en torno a una novedad científica y cultural: un sistema de navegación por los aires.

«He dividido mi trabajo en dos partes: la primera versa sobre las objeciones teóricas al arte de volar. A la primera objeción teórica la llamo objeción de las alas infinitas. El señor de Cárdenas afirma que para que un hombre se sostenga en el aire basta dotarlo de un sistema de alas fabricadas de un material liviano. Estas alas, debido a su gran superficie, tendrían por objeto ofrecer resistencia a la fuerza de la gravedad e impedir la caída del cuerpo volátil. Ahora bien, por livianas que sean estas alas, tienen un peso, y para que ese peso no origine la caída, será necesario colocar otras alas para las alas. Pero a su vez, este nuevo juego de alas, que también pesa, requerirá otro juego de alas que las sostenga y éste a su vez otro y así indefinidamente. De este modo, el ingenio volador del señor de Cárdenas será un encadenamiento infinito de alas».

(Ribeyro 1966: cuadro cuarto)

Ya desde la presentación de su informe y al usar la sustantivación con valor adjetival peyorativo pajarero para referirse a Santiago, Cosme Bueno anunciaba su actitud frente a la novedad propuesta. De donde -y más allá de las sonrisas que pueda arrancarnos- resultase «académicamente contundente» el principio de las alas infinitas. No extrañaría, entonces, la sentencia final que daría Cosme Bueno sobre la posibilidad de que el hombre volase algún día.

«Me parece que ha quedado suficientemente demostrado, con ejemplos y argumentos, el carácter irracional de la Memoria presentada por el señor de Cárdenas. Quiero agradecer a nuestro ilustrísimo Virrey quien ha encomendado a mis pobres luces la refutación de tan peregrina teoría y a mis leales colegas (Señala al cuerpo docente, uno de cuyos miembros se ha quedado dormido), cuya comprensión y estímulo me han alentado en todo momento. Una vez más, esta ilustre Casa de Estudios, pozo de ciencia y de saber, sale en nombre de la verdad, para refutar a los advenedizos y audaces sostenedores de nuevas teorías».

(Ribeyro 1966: cuadro cuarto) 
¿Cuál es el vínculo subyacente a la asociación que se establece entre «advenedizo» e «irracionalidad». Lo explicita el mismo Cosme en otro pasaje de la obra teatral:

«Ni Aristóteles, ni Platón, ni Plotino, ni Santo Tomás, ni Duns Scoto, ni el Reverendo Padre Bernardino de la Orden Carmelita, se ocupan en sus sapientes tratados de la posibilidad en el arte de volar. Toda nuestra ciencia está contenida en los filósofos de la antigüedad. Nosotros no somos más que humildes glosadores dedicados a comentar e interpretar los textos inmortales. Quien intente salirse de este sendero se precipitará de las nubes de sus quimeras en el abismo del error...».

(Ribeyro 1966: cuadro cuarto)

Hoy forma parte de la naturaleza artificial del ser humano lo que ayer se llamaba promesa del arte de volar y hoy es ciencia. Hoy, tanto los análisis del discurso como los trabajos de las neurociencias nos ponen ante la evidencia de que las tecnologías de la información -palabra hablada, escrituras fonética, ideográfica y hoy electronal- no son simples plataformas inocuas respecto a los procesos cognitivos y a los efectos sociales que la impronta de cada tecnología sedimenta en la mente de sus usuarios. Recordemos aquí -solo por citar algunos- los trabajos de Milman Parry, Eric Havelock, Walter Ong, Susan Greenfield y Bruce Lahn.

«Durante mucho tiempo 'racional' ha significado, para occidente, uniforme, continuo y secuencial. Dicho de otro modo, hemos confundido la razón con el saber leer, y el racionalismo con una sola tecnología. Así, en la edad eléctrica, el hombre parece volverse irracional para el Occidente convencional» (McLuhan 1969: 36).

Volvamos entonces ahora a la Universidad de San Marcos y a Santiago, el pajarero. Porque lo dicho por Marshall McLuhan respecto a la cultura occidental, en el sentido de que esta crea un isomorfismo finalmente totalitario entre racionalidad y escritura alfabética, es sustrato de lo sostenido por Cosme Bueno: aquello que no se atenga a la lógica derivada de esta escritura será «irracional y advenedizo».

Bajo estas premisas es fácil advertir el desprecio por lo oral y las culturas orales y la desconfianza -y aun anatema- hacia el advenimiento de la palabra electrónica. Con cargo a explicarlo gradualmente, hemos vivido en una zona de confort signada por el dominio excluyente y mercantilista del código alfabético.

Fue el estudioso canadiense Harold Innis (1894-1952) quien en sus obras The Bias of Communication y Empire and Communications nos puso en la pista de la importancia de la sustancia de las tecnologías en orden a sus efectos culturales. 
Respondiéndose Innis acerca del papel que había jugado el ferrocarril en la configuración de su país natal, llegó a la conclusión de que, con prescindencia de aquello que el ferrocarril transportase, era la sustancia de la tecnología llamada ferrocarril la que explicaba el hacerse de Canadá. Fueron estas observaciones y este razonamiento lo que lo llevó a distinguir entre medios de comunicación que -por la naturaleza de su sustancia- estaban unos más ligados al dominio del tiempo y otros más ligados al dominio del espacio. Mientras la piedra o la arcilla, por ejemplo, eran sustancia de dominio temporal por su perdurabilidad, el papiro o el papel constituían sustancia que por su liviandad posibilitaba la expansión en el espacio.

Como lo señala Albert d'Haenens -con quien tuvimos la satisfacción de compartir ideas en la universidad de Lovaina la Nueva-: «Para nosotros, occidentales, la anterioridad solo es legitimada y digna de consideración en tanto sea substantificada» (D’Haenens 1993: 10). El problema es que para ese occidente, tal como lo hemos venido viendo y como lo explica maravillosamente el profesor D'Haenens en su libro El texto traza de la anterioridad escribal, la única sustancia legitimada y aun sacralizada fue aquella de la palabra escrita con caracteres alfabéticos. Al hacer esto se excluía y aun negaba tácita y arbitrariamente que la palabra hablada tenga una sustancia diferente y relevante, así como la tiene hoy la palabra electrónica.

Todo este mercantilismo cultural -el reduccionismo del mundo a un solo código, el alfabético- pudo ser sustentado falazmente ayer, aceptando implícitamente que la palabra escrita constituía el estadio superior. Aquel estadio al que se refiere Alvin Toffler cuando dice:

«Newton parecía haber descubierto las leyes que programaban a los cielos. Darwin había identificado leyes que programaban la evolución social. Y Freud, supuestamente, revelaba las leyes que programaban la psiquis. Otros -científicos, ingenieros, científicos sociales, psicólogos- seguían buscando todavía más, o diferentes, leyes. La civilización de la segunda ola tenía ahora a su disposición una teoría de la causalidad que parecía milagrosa por su poder y su amplia aplicabilidad» (Toffler 1984: 74).

Ese concepto de segunda ola de Alvin Toffler es aquel de la masificación de las sociedades. Masificación solo posible merced a la imprenta, a la escuela pública y a los primeros medios de comunicación precisamente masivos. Todos ellos asegurando para las sociedades donde actuaban la impronta de la homogeneidad en lo -y retomamos lo dicho por McLuhan- «uniforme, continuo y secuencial». Herencias claras de la escritura alfabética.

¿Cómo compatibilizar ese mundo de homogeneidad con la afirmación de diversidad cultural -cada vez más creciente- a la que nos conduce hoy la palabra electrónica? ¿Podemos seguir sosteniendo categorías de mercantilismo para explicar la larga duración de la humanidad? 
Cuando hablamos de larga duración de la humanidad estamos refiriéndonos a los ciento cincuenta mil años que tiene el ser humano afirmado como especie diferenciada. Durante este recorrido, palabra hablada y oralidad signaron un largo periodo hasta la aparición de las escrituras. Y si pensamos en Occidente no está de más subrayar que, desde la invención de la escritura alfabética hasta que esta fue perdiendo su posición de dominio por influencia de la palabra electrónica -de la cual es difícil situar sus confines-, estamos hablando de dos mil ochocientos años.

Si asumiésemos que ciento cincuenta mil años constituyesen veinticuatro horas de una vida, ¿sería válido intentar explicar la anterioridad y la posterioridad de aquella vida por lo que ocurrió en aproximadamente veintisiete minutos? Si acaso suscribiésemos esto último, no deberíamos sonreir tanto al leer el intercambio final de palabras entre Santiago de Cárdenas y el académico Cosme Bueno. Porque de hecho parecería que estuviésemos suscribiendo aquello que nos causó risa: «iLa razón, señor, está en los libros y usted no ha leído nada!». Mercantilismo cultural.

Convendría, entonces, tomar distancia de los mercantilismos culturales. Gérmenes de exclusión, intolerancia, indiferencia respecto a la diversidad y no poca violencia. Para lograrlo, será importante que no aceptemos la legitimidad de una sola sustancia de las tecnologías de la información, sino que aceptemos el hecho empírico de la existencia de sustancias diferentes y relevantes para la palabra hablada, las escrituras y la palabra electrónica. No hacerlo implicaría no aceptar lo que el análisis semiológico y las neurociencias nos van señalando: cada tecnología de la información ha dejado y dejará huellas no solo en la externalidad de nuestra vida social, sino en la operatividad y el funcionamiento mismo del cableado cerebral.

En esta línea de razonamiento nos encontramos hoy con el poder invasivo y creciente de la palabra electrónica. Y a este punto, hacemos nuestras las palabras de Cohen Séat y Fougeyrollas:

«Los múltiples cambios ocurridos en los diversos niveles de la condición humana podrían acabar mañana por causar una variación radical y global de algún aspecto importante de esta condición y merecer el nombre de mutación en todo el sentido de la palabra» (Cohen-Séat y Fougeyrollas 1980: 9).

Hacemos nuestras estas palabras con una precisión. Desde el punto de vista de la larga duración y de las tecnologías de la información en el tiempo, la mutación no solo hay que esperarla mañana. Es obvio que una primera mutación ocurrió en esa condición humana invocada por los autores citados con la propia aparición del instrumento lingüístico; y una 
segunda -en Occidente-con la invención, difusión y penetración de la escritura alfabética que devino en escribalidad.

Frente a la palabra electrónica no cabe que nos refugiemos en el isomorfismo entre razonamiento y lectura/escritura alfabéticas. Retomemos nuevamente a Cohen-Séat y a Fougeyrollas y reflexionemos con ellos sobre estas sus palabras:

«Antaño el hombre cultivado podía servir de modelo [...] El ideal a alcanzar, gracias a la propagación del saber, según un proyecto humanista, era favorecer la multiplicación de hombres cultos o susceptibles de llegar a serlo, hasta alcanzar el número más alto posible. Veremos que difícilmente podría decirse que en la actualidad el hombre cultivado controle mejor que el no cultivado la acción que sobre él ejerce la información general, y sobre todo la información visual, al afectar profundidades de su personalidad que aún no han sido suficientemente exploradas, y sobre las cuales no hemos adquirido poder deliberado» (Cohen-Séat y Fougeyrollas 1980: 18).

Poco reparamos ya en ello. Sin embargo, la asociación alfabeto fonético-imprenta-escuela pública para la alfabetización masiva supuso dejar de lado prácticas culturales estrechamente vinculadas al largo periodo del imperio de la palabra hablada.

Nuestras capacidades mnemotécnicas para recordar se vieron debilitadas, pues no hacía falta retener en la memoria aquello que las escrituras parecían consignar con mayor fidelidad. Nuestras competencias y habilidades para el cultivo del ritmo se vieron silenciadas porque el ritmo fue efectivamente -en sus orígenes- instrumento de ayuda para la memoria. La hermosa y larga epopeya cultural de la caligrafía y de la ilustración de códices se vio de pronto y abruptamente cercenada por los caracteres de la imprenta. Dejamos el canto colectivo y posibilitamos con esa imprenta el canto individual. Finalmente -y solo por citar aquí algo de lo que se dejó de lado-, la sabiduría ligada a los años de experiencia la reemplazamos por la excluyente frialdad del razonamiento escribal.

La palabra electrónica y la cultura de la electronalidad han originado ya veloces supresiones de lo anterior, así como vienen configurando nuevas potencialidades. Nuestra propia experiencia vital, para no aludir excluyentemente a la comprobación científica, nos habla ya del debilitamiento de la memoria de largo plazo y del privilegiamiento de la memoria de corto plazo. Nos dice acerca de la recuperación del ritmo en detrimento de la melodía. Nos señala, en fin, el readvenimiento del canto social, pero esta vez virtual. Donde el yo individual se produce y muta constantemente en orden al canto de los demás que nos interesan.

Tal es la dimensión del cambio del cual recién empezamos a tomar nota de su profundidad, que -como dicen Cohen-Séat y Fougeyrollas- «difícilmente podría decirse que en la actua- 
lidad el hombre cultivado controle mejor que el no cultivado la acción que sobre él ejerce la información general, y sobre todo la información visual [...] y sobre las cuales no hemos adquirido poder deliberado» (Cohen-Séat y Fougeyrollas 1980: 18).

Si bien para nosotros -y ya lo hemos señalado líneas antes- los medios masivos de comunicación fueron en sus inicios un altavoz de la escribalidad, en el sentido de reafirmación de la homogeneidad, conviene rescatar el carácter extrapolable de unas palabras de Umberto Eco respecto al fenómeno de los mass media:

«deberemos discutir los distintos problemas partiendo del supuesto histórico y antropológico-cultural a la vez, de que con el advenimiento de la era industrial y el acceso al control de la vida social de las clases subalternas, se ha establecido en la historia contemporánea una civilización de mass media, de la cual se discutirán los sistemas de valores y respecto a la cual se elaborarán nuevos modelos eticopedagógicos» (Eco 1968: 41).

Palabras útiles si queremos abordar en su verdadera medida los alcances y el dimensionamiento de la palabra electrónica y de la electronalidad. Estamos ante una nueva mutación de la condición humana «de la cual se discutirán los sistemas de valores y respecto a la cual se elaborarán nuevos modelos eticopedagógicos».

\subsection{Están en otra}

Los jóvenes acuñaron la frase hace ya algún tiempo. Para referirse a una persona o a un grupo de personas con las cuales es imposible establecer relaciones. Porque por diversas causas esa persona o grupo se han desentendido de la realidad o de nosotros.

Y están en otra quienes aún quieren pensar que la electronalidad es solo una tecnología que permite hacer ahora de modo más veloz las cosas que hacíamos antes. Que conciben al ordenador -entonces- simplemente como una máquina de escribir más rápida.

Están en otra quienes -sin profundizar en el análisis de los discursos- no advierten que, así como la tecnología de la información de la imprenta cambió nuestras categorías conceptuales y nuestro propio modo de ver el mundo, lo mismo está ocurriendo con la tecnología de la información electronal.

Están en otra quienes, ignorando lo que nos dicen la lingüística, la semiótica y las neurociencias, no se percatan de que han cambiado nuestros modos de producir y consumir sentido y que ello se comprueba no solo en el análisis discursivo, sino en el propio cableado cerebral. 
Están en otra, en fin, quienes creen que es posible mecánicamente traducir y trasladar las categorías del mundo anterior -cuya única fuente de información era el libro sacralizado y en que los receptores eran solo consumidores de signos producidos por terceros- a discursos provenientes de una tecnósfera de fuentes varias y desacralizadas y donde los receptores no son más solo consumidores, sino productores.

Digámoslo claramente. Por estar en otra, por ejemplo, muchos prefieren seguir usando el término literacidad digital para aludir al nuevo mundo que se está configurando. Sin percatarse de que -por lo pronto- los conceptos de una disciplina tienen que servir para describir aquello a lo que se refieren. Y cualquier persona que esté leyendo este texto sabe que en las pantallas de sus computadoras, de sus tablets, de sus smartphones, hay -a diferencia del libro- permanentes instantaneidades efímeras; fotografías, videos, música, emoticones... donde las mismas letras tienden a evanescerse para muchas veces convertirse en íconos. Ante esta realidad del discurso, ¿por qué persistir en esta falta de rigor metalingüístico?

¿Cómo referirse a literacidad digital -evocando la cultura del libro y la preponderancia de la letra- cuando el habla electrónica configura un «discurso sin fin»? Ni el inicio ni el fin de las intervenciones de los hablantes electronales están marcados, y ello explica, entonces, que los participantes en este tipo de comunicación puedan sustraerse transitoriamente (se van porque algo tienen que hacer o simplemente se cansaron) y que puedan retornar de improviso (¿no es acaso cierto que la gente está conectada todo el día a la espera psicológica de cualquier comunicación?).

Curioso que la mayoría de quienes evaden el rigor lo hagan a veces en nombre del hombre de Vitruvio. Del hombre culto y meditabundo del Renacimiento. Producto precisamente del rigor.

Igual ocurre con la expresión alfabetización digital. Tentación expresiva en la cual a veces se incurre a pesar de que sabemos que el código de la escritura electronal es otro y la escritura alfabética, allí, se tambalea.

La única explicación plausible sería que están (o estamos) en otra. Y que creemos o queremos mantenernos en una imaginaria zona de confort para perpetuar un -ahora- imaginario poder. Aquel del monopolio mercantilista del libro sacralizado. Cuando el análisis de los discursos va diciendo objetivamente cuál es el sentido de los cambios.

\subsection{Prejuicios y perjuicios}

Un orador de las calles de Lima repetía una expresión que recogimos en un libro y que nos pareció reveladora de la realidad cultural del Perú: «Enseñarle un libro a un peruano es como enseñarle la cruz a Drácula». 
Más allá de la sonrisa que pueda generarnos la citada expresión, nos da pie para hacer algunas reflexiones.

Primero. Aun cuando algunos parezcan pensar lo contrario, Bruce Lahn, el brillante biogenetista de la Universidad de Chicago, ha subrayado con sus investigaciones que el cerebro humano sigue evolucionando.

Segundo. Susan Greenfield, la más notable neuróloga británica de la actualidad y profesora en la Universidad de Oxford, ha dicho que el funcionamiento del cerebro está cambiando ya por influencia de las nuevas tecnologías de información electrónica. Y sostiene que la computadora -como la refrigeradora o la televisión- no solo sirve para añadir confort y rapidez a nuestras vidas y procesos.

Tercero. Como veremos en detalle en el punto 1.4 de este capítulo -y esto es sustancial-, la investigación lingüística, semiológica y neurológica demuestran que los patterns o modos de producir sentido DIFIEREN, en personas adscritas a las tecnologías de la información, de la palabra hablada, de la palabra escrita y de la electrónica.

Cuarto. Es claro que todo lo anterior nos lleva a una conceptualización de nuevos públicos objetivo. Que se definen por los criterios mencionados.

Este es el contexto en que debe situarse el tema de las lecturas y las escrituras en el Perú. Y el tema de la influencia de la electronalidad en nuestra sociedad. ¿Es cierto que enseñarle un libro a un peruano es como enseñarle la cruz a Drácula? ¿Es cierto que los peruanos no leen? ¿Es cierto que el libro sigue teniendo el monopolio de la información confiable? ¿Valdría la pena afirmar, entonces, que mejor sería hablar de lecturas y escrituras? ¿No es acaso cierto que la computadora se activa también leyendo? Y, por último y dados los cambios producidos, ¿no será cierto que los jóvenes que no leen libros pero que practican una escritura electrónica en la cual se evanescen las vocales -por ejemplo- decodifican ya de otra manera?

Hoy, que asistimos prácticamente a cruzadas evangelizadoras en la lectura, nos preguntamos si quienes las promueven se hacen estas necesarias interrogantes y tratan de responderlas. En cuyo caso estaríamos ante una sana preocupación. ¿ 0 es que acaso la cruz de Drácula no es sino un tótem mágico que esconde temor -lo dijimos antes- ante el fin del monopolio y el mercantilismo del libro? Porque si algo reintroduce la electrónica es la posibilidad de que el individuo -como ayer, con la palabra hablada- sea consumidor y productor de signos a la vez. Tiempos difíciles, ciertamente, sobre todo para las intolerancias y los autoritarismos.

Veamos ciertas expresiones comunes que son más producto de la ceguera que de elucidación: 


\section{«Solo la lectura nos hizo y nos hace humanos»}

Falso. No lo solemos recordar, pero sabemos que la escritura alfabética -legado griego- data del 800 a. C. El vaso de Dípilon lo testimonia así. Pero nos resistimos a recordar que durante siglos las mayorías no supieron leer ni escribir. Eppur... si muove!

La imprenta ayudó a crear el objeto libro. Sin embargo, fue a finales del siglo XIX que la humanidad se abocó a la tarea de la alfabetización masiva. Había que crear una mente masa para consumir los preciados y seriados productos de la gran industria y aun de la política y sus categorías.

¿Habrá razones culturales y científicas para considerar que solo la lectura nos hace humanos? ¿Cuándo el libro dejó de ser fuente única de información y empezó a competir con las tecnologías electrónicas? ¿No hubo historia ni hombre ni arte ni civilización antes de lo escrito? ¿Tampoco lo habrá en el mundo electronal?

Ante el fácil expediente del desprecio de la oralidad y su significado en la construcción de lo humano, pensemos que los jóvenes podrían ya encogerse de hombros ante una tecnología que, como la imprenta, ya fue. Para decirlo acudiendo nuevamente a una expresión lingüística de muchos jóvenes de hoy.

No creemos que sea consuelo seguir contentándonos con ser pretendidos guías de una sociedad pastoril -Sloterdijk- donde asumimos ingenuamente que todos continúan consumiendo instrucciones ajenas. Hemos pasado de una memoria ROM (archivo) a una memoria RAM (procesamiento). 


\section{«País que lee, país que cambia»}

Falso. Ya los viejos griegos -aquellos amantes de la retórica clásica, argumentativa y servidores de la democracia contra las tiranías- distinguían entre discursos de re-uso y discursos de consumo.

Los primeros -o sea los discursos de re-uso, fundamentalmente ritualidades laudatorias o celebratorias o códigos de sujeción de conductas- apostaban por mantener el orden establecido. Recitados o leídos, perpetuaban poderes, saberes y modelos sociales.

Los segundos, aquellos de consumo, eran discursos destinados a enfrentar una situación problema inédita y a plantear una solución.

Un país de frágil institucionalidad y -por ende- gobernabilidad, un Estado construido de espaldas a sus usuarios, requiere (y esto es más que evidente) de la formulación de discursos de consumo, más aún en el mundo cambiante en el que nos movemos. Es un deber de la Academia develar el sentido de los cambios.

¿Serán las lecturas canónicas y sacralizadas las que nos acercarán al cambio? ¿Es la lectura prescriptiva, realmente, arma de consumo?

Si lo pensamos bien, no hay pruebas destinadas a medir la escritura. Y sí las hay para medir supuestamente la lectura. Al leer, solo se lee. Al escribir, hay dos operaciones: lectura y escritura. Pero no. No se le mide. Ello a pesar de ser la escritura arma de consumo. ¿O será por eso que no se le mide?

Entonces, país que escribe, país que cambia. No solo es más académico: es, en puridad, más respetuoso de la vida. 


\section{«La computadora nos hace leer menos»}

Falso. Moneda sin respaldo. Lo hemos dicho alguna vez: tanto o más grave que la inflación económica lo es la inflación de las palabras. 0 sea, emitir nombres sin respaldo. 0 sea, falsificar el conocimiento.

Se ha convertido en un cliché decir que la gente joven lee menos. A veces nos asalta la duda de si las personas que contribuyen a la circulación de estas emisiones inorgánicas han ingresado alguna vez a una cabina pública de internet o se asoman al quehacer de sus hijos frente al computador.

¿Cómo se activa un ordenador, para comenzar, si no es a través de la lectura de instrucciones y de la escritura de signos? ¿Se activa, acaso, por ósmosis? ¿Acaso no hay que leer para que ese aparatito «perverso y diabólico» se ponga en marcha?

El fenómeno del masivo uso de cabinas públicas de internet ha sido profusamente estudiado. Gran número de personas que en el Perú acceden a internet a través de cabinas públicas -que según el INEI alcanza el 30\% de la población- leen. ¡Y esas personas no precisamente han cambiado El ingenioso hidalgo... por internet! Antes no leían nada. ¡Y son más de 6000000 de usuarios de internet en el Perú!

Pero hay más. Los buscadores -Google, Yahoo, MSN, Terra, Wikipedia, etcétera- son consultados por niños y jóvenes para sus tareas. Por adultos para trabajos profesionales. Por médicos e ingenieros. Por amas de casa y humildes campesinos que inician su «alfabetización digital». ¿Ellos tenían antes a su disposición surtidas y actualizadas bibliotecas para solucionar sus dudas?

En ámbitos acaso más domésticos, es claro que los e-mails, los blogs o Facebook circulan e interrelacionan hoy más gente que las viejas cartas (o libros) de ayer. ¿Y no se lee ni se escribe allí tampoco?

Que la gente no esté leyendo lo que «nos gustaría» es otro problema. Que la gente no solo lea, sino escriba -como señalamos-, también es otro asunto. El problema sería tal vez más serio si nos planteásemos si leer en pantalla es igual que leer en el objeto físico llamado libro.

Y aquí sí nos encontramos con el quid o esencia del asunto: los jóvenes leen menos libros, lo que no significa que lean menos. Si la Academia no se cuestiona -como no suele hacerlo- tipos diferentes de lectura, ¿le estará, entonces, preocupando más el tótem libro que la lectura en sí? 


\section{«A mayor razonamiento verbal, mejor escuela y mejor país»}

Falso. Un distorsionado principio de simplificación administrativa parece haber llegado a las escuelas peruanas. $\mathrm{O}$ al menos a las recomendaciones que se hacen para mejorarlas. Es lo que viene ocurriendo con el excesivo énfasis que estamos poniendo en el llamado razonamiento verbal (RV) y también en la prueba PISA.

A falta de propuestas integrales -que atiendan diferencias e inteligencias múltiples- y guiados por un costo/beneficio dudosamente escolástico, hay quienes afirman que la escuela nuestra podría darse por satisfecha si alcanzamos resultados satisfactorios al menos en las pruebas de RV.

Tal vez nos hemos olvidado de que las pruebas de razonamiento verbal y matemático llegaron a nosotros para «estandarizarnos» y por esa vía «facilitar» los ingresos a algunas universidades. Imposibilitadas de corregir «redacción», las universidades corrigieron aspas o marcas. En orden a medir -se sostenía- el denominado IQ.

Pronto las academias de ingreso a las universidades comprendieron el negocio. Y se especializaron no en el razonamiento verbal, sino en el «condicionamiento de la respuesta correcta» vía descarte. ¿O alguien, en su sano juicio, puede creer que es factible enseñar a «razonar» en dos, tres o seis meses?

Luego este mismo método -que supone entrenadores y no maestros, en la mayoría de los casos- pasó a secundaria. Primero a quinto, luego a cuarto... iy hoy se ha enseñoreado ya en la educación primaria!

No estamos enseñando a razonar verbalmente a nuestros estudiantes: ¡los estamos amaestrando para marcar el aspa de la respuesta correcta!

¿Por qué no enseñar a argumentar a nuestros alumnos? ¿Por qué no ponerlos en condiciones de interpelar palabra hablada, escrita y electrónica? Esa argumentación es ejercicio de la lengua oral. 


\section{«La literatura nos acerca amablemente a la lectura»}

Falso. Hoy enseñamos a leer -lo hemos insinuado ya, leer cualquier cosa, no importa- con la «amable» literatura.

De hecho, los niños y niñas de los primeros grados de primaria leen y recitan poemas como parte de su etapa de aprendizaje para la ulterior lectura «seria». Conviene recordar al respecto que hace mucho la lingüística distinguió la función poética del lenguaje de las funciones representativa o metacognitiva. La función poética no conduce a las otras funciones. Peor aún: puede hasta causar desajustes en la decodificación, pues una apela a la connotación instrumental y a la polisemia y la otra -por el contrario- a la denotación y a la univocidad.

Entonces, ¿será un aserto honesto -a propósito de nuestra escuela y de las campañas de lectura- aquello que dice un recurrente poema de los textos escolares?:

«Te lo debo a ti, maestra...

¡Dios te dé su bendición!

Ya sé leer y muy pronto

me graduaré de Doctor!».

(Carmen Natalia)

\subsection{Escritura electronal: patterns de producción de sentido}

\subsubsection{Adiós al ELLO objetivado: porque me gusta, pues}

Todos asistimos hoy a la dificultad que tienen los jóvenes para alcanzar definiciones objetivas. Cuando a uno se le pide la definición de algo, constatamos que sus respuestas casi inevitablemente van precedidas de demarcadores que eluden la definición directa y que al mismo tiempo nos señalan el interés del joven por mostrar una definición en perspectiva, una definición surgida desde la posición del codificador. Esta no es la definición, es mi definición, codificada para ti en estas circunstancias.

¿Qué demarcadores traducen este perspectivismo del hablante? Nos estamos refiriendo a que, ante la exigencia de definiciones objetivas, los jóvenes responden empleando demarcadores como es como si, o sea, por ejemplo, entonces. 


\section{Veamos:}

Es como si (que nos lleva a una comparación, no a una definición)

O sea (implica una comparación con un antecedente que no ha sido formalmente expresado)

Por ejemplo (alude a un caso, no a una definición)

Entonces (se refiere a un antecedente no explícito del cual se está dando la consecuencia)

En todos estos casos, el ello está siendo puesto en perspectiva desde el yo que habla, involucrando al tú con quien estamos hablando. El ello objetivo entonces se relativiza y esta es una constante que comenzamos a verificar en el empleo del lenguaje por parte de los jóvenes. En Europa, en el Perú y donde se quiera.

Estamos ante un cambio en la función representativa del lenguaje. Un cambio consistente en que el ello objetivado nos ha sido enajenado culturalmente. Para bien o para mal. El sentimiento lingüístico de los hablantes comunes pareciese no interesarse en definiciones absolutas y fuera de contexto.

¿Qué es lo que está produciendo este cambio? A nuestro juicio, la electrónica. Los lenguajes de la televisión y de la informática parece que cumplieran con mayor eficacia para los hablantes la función de objetivar, y así esos hablantes -a partir de su «sentimiento lingüístico»-se sienten libres de la obligación de objetivar, propiciándose una mayor expresividad y una mayor apelación en el uso de los instrumentos lingüísticos.

Los hablantes se encuentran ante un mundo en el cual ya no es posible hablar de una tercera persona ajena, pero culturalmente han sido entrenados para hablar en tercera persona, para ocultar su mundo interior, para no mostrar sus motivaciones hacia el receptor. Y si esto es así, transitan estos hablantes una etapa en la cual -privados de la tercera personaaún no están culturalmente condicionados para dar rienda suelta al yo y al tú, y pasamos así por un periodo en el que los mensajes aparecen fundamentalmente como fáticos, inexpresivos e inapelativos.

La resistencia al cambio nos está llevando, por ejemplo en el terreno de la educación, a tratar de seguir manteniendo una escribalidad ficticia. Las propias universidades, por comodidad didáctica y ante la pérdida de la función representativa del lenguaje entendida como objetividad pura, están jugando el papel de la contigüidad sin quererlo. Las pruebas objetivas, sobre las cuales hemos ya adelantado algo, proponen al estudiante un contexto artificialmente construido, le objetivan una realidad que el joven tiene que sentir extraña, pero le plantean simplemente -con las alternativas- una reacción verbal. Pedimos disculpas, pero, para quien conozca el célebre trabajo de Roman Jakobson sobre las afasias (pér- 
dida total o parcial del habla), estamos tratando a nuestros estudiantes como afásicos de selección deficiente. Estos afásicos son capaces de reaccionar por influencia de contextos prefabricados. No los pueden construir, pero sí están facultados para reaccionar ante ellos. Las equis o aspas de las pruebas objetivas no son sino un crudo testimonio de la cerrazón al cambio y de los vanos intentos por mantener una escribalidad vacua.

Pero aun más: a pesar de la renuncia que los hablantes vienen haciendo en torno a una representación objetivada, a un ello impersonal, a una tercera persona gramatical ajena, la escuela -incluida la universidad- llega hasta a reprimir la expresividad. El principio de que el mundo académico demanda objetividad lleva a prohibir -en algunos exámenes, grados o tesis- el uso de la primera o de la segunda persona gramatical. Todo debe estar redactado en tercera persona: con ello no hacemos otra cosa que inhibir la capacidad de opinión del hablante. Ello se produce aun en facultades o escuelas de comunicación.

El rigor exige ciertamente la representación. Pero -hoy más que nunca- exige también el punto de vista de la persona. Inhibiendo el punto de vista no alentaremos la reconstrucción del ello objetivado.

\subsubsection{El eclipse de la metáfora: no ames a tu prójimo como a ti mismo}

Así como en el sistema cultural de la escribalidad la grafía que representaba al sonido posibilitaba objetivar y, entonces, favorecía las asociaciones por semejanza (metáfora), la cultura de la oralidad y ahora de la electronalidad, que no aprisionan los sonidos y que están signadas por el perspectivismo del ello, privilegian más bien las asociaciones por contigüidad (metonimia).

Para algunas personas, leer o escuchar las palabras metáfora y metonimia puede resultar atemorizante. Tal vez porque dichas palabras evoquen cursos olvidados en el tiempo. Quizá porque eso de semejanza o contigüidad puedan aparecer como términos cuyas fronteras serían difíciles de precisar.

Sin embargo, la comprensión del asunto es sencilla.

«Dime con quién andas y te diré quién eres» es una expresión bastante popular. Y todos sabemos lo que significa.

Una candidata política, entre nosotros los peruanos, se convirtió en la «candidata de los ricos» a pesar de que ni su aspecto físico en sí ni su propia manera de vestir se semejaba al modelo de mujer adinerada que la gente tiene en su mente. ¿Qué ocurrió para que esta dama política llegue a cargar con esa imagen? Sus apariciones públicas contiguas a personas que sí tenían esas características posibilitó el endose semántico. 
La candidata, así, no era una metáfora de los «ricos», pues no guardaba relación de semejanza con ellos; se le asociaba así simplemente por contigüidad, por metonimia.

En el caso del renunciante papa Benedicto XVI, estamos frente a una figura considerada distante y fría. Quién sabe si lo sea o no. Pero lo que ocurre allí es que, por semejanza, el buen Benedicto XVI es una metáfora de otros papas (Pío XII, Paulo VI) que ya tenían esa imagen.

Metáfora y metonimia, entonces, semejanzas y contigüidades, son figuras de asociación que configuran nuestros modos individuales y colectivos de ver las cosas cotidianas y el mundo mismo.

Recordemos con Roman Jakobson que

«dos son las directrices semánticas que pueden engendrar un discurso, pues un tema puede suceder a otro a causa de su mutua semejanza o gracias a su contigüidad. Lo más adecuado será hablar de desarrollo metafórico para el primer tipo de discurso y desarrollo metonímico para el segundo» (Jakobson 1967: 95).

Reparemos: dos directrices. Solo dos. Y, como consecuencia de la relación que los usuarios establecen con su instrumento lingüístico -haya marca o neutralización del perspectivismo lingüístico-, los hablantes privilegian la metáfora o la metonimia. Entiéndase bien: privilegian. Pero es claro que este privilegiamiento contribuye a configurar formas de expresión y de contenido, mecanismos de producción de significado. Finalmente, espacios de representación e imaginarios.

Tratemos de decirlo en términos quizá más simples. Cuando los hablantes se mueven en un mundo de objetividades -y ello ocurre en el sistema cultural de la escribalidad-, es más frecuente el privilegiamiento de la metáfora. Pues esta, al ser una figura de sustitución basada en la semejanza, se verá favorecida en un mundo que permite precisamente objetivar esa semejanza. Obviamente, es más fácil establecer nexos de similaridad cuando se trabaja en el mundo de la tercera persona gramatical claramente diferenciado respecto al yo y al tú, a la primera y a la segunda persona gramatical.

Todo lo contrario ocurre cuando los hablantes se mueven en un mundo signado por el perspectivismo respecto al ello. Cuando el ello se ve desde los intereses del yo y el tú, cuando el mundo externo ajeno a los hablantes nunca es finalmente ajeno a esos intereses, las semejanzas se hacen menos fáciles por su propia inutilidad expresiva y -de ese modo- se privilegian las figuras de sustitución metonímicas. 0 sea, aquellas basadas en la contigüidad, aquellas que saben más del aquí y del ahora, de los intereses y puntos de vista de los usuarios, de los contextos existentes. 
¿Qué significó, culturalmente, el imperio de la metáfora? ¿Qué implicó, entonces, el privilegiamiento de las semejanzas? ¿Qué repercusiones tuvo la represión del yo y el tú individuales? Dio lugar al mundo de los semejantes. Al mundo de los homogéneos. Donde la diversidad era una categoría per se excluida.

Si repasamos prácticas sociales ocurrentes y ocurridas, nos tropezaremos con grandes cruzadas emprendidas -no con poca violencia- en aras de la homogeneidad. Para la exclusión o aun desaparición de lo diferente.

Pues bien. Si la escribalidad propicia la metáfora, la oralidad y la electronalidad insurgente propician la metonimia. De allí que el mundo que se está configurando sepa más de lo diverso como valor que de lo estandarizado y homogéneo. De allí que los medios cada vez más desmasificados y diversificados, tantos como públicos-objetivos distintos, se impongan sobre emblemáticas insignias representativas de la verdad (una) y la homogeneidad (todos somos iguales).

Habíamos sido educados en la idea de que «Dios creó al hombre a su imagen y semejanza» y de que debíamos amar al prójimo como a nosotros mismos. Pues bien: entendamos que esta propuesta fundacional, inmersa en un mundo que privilegia semejanzas y homogeneidades, privilegia así el amor a los semejantes. De allí que tal vez sea preferible, hoy, amar al prójimo como a él mismo. En su diferencia.

Es presumible que muchos de quienes están leyendo estas líneas hayan vivido la experiencia. Sus padres o sus madres -ciertamente con la mejor intención del mundo- probablemente los pusieron en las escuelas a las que ellos acudieron. Seguro aspiraron a que tal o cual profesor que a ellos los formó tuviese la responsabilidad de educar a sus hijos. Y seguro indujeron en estos su vinculación a cierto tipo de actividades escolares con las que padres o madres se vincularon ayer.

Avanzado el tiempo, esos mismos padres o madres pueden haber pretendido que los hijos compartan las mismas aficiones y gustos. Y, avanzado aun más el tiempo, haber ambicionado que sus hijos siguiesen las mismas profesiones o quehaceres -al menos, afines- que asegurasen una continuidad y proximidad familiar. De hecho, los nombres mismos de los hijos suelen reproducir los nombres de algún miembro de la familia.

Pues bien. Si caemos en la cuenta, el natural concepto de reproducción lo hemos hecho extensivo -por un largo periodo- al mundo social y cultural de nuestros hijos. Criados y educados en tradiciones inmersas en la homogeneidad, crecidos al calor de la copia y la repetición impuestas por la educación escolar, hicimos nuestra la idea de que Dios creó al hombre a su imagen y semejanza y pretendimos convertir a nuestros hijos en una metáfora -figura de sustitución por semejanza- de nosotros mismos. 
De pronto, nada de esto parece ser ya posible. Por diferentes razones, los hijos no acuden a la escuela a la que asistieron sus padres o madres. Los profesores simbólicos de tal o cual colegio pueden haber devenido en recuerdos. Los quehaceres o actividades de ayer no parecen atraer a los niños y jóvenes de hoy. La oferta de profesiones ha aumentado y con ello se abre más la posibilidad de escoger. Tal vez la empresa a la que muchos progenitores dedicaron gran parte de su vida (probablemente como sus padres) no exista ya o no despierte el interés de los hijos por laborar en ella.

En cualquier caso, la realidad nos pone ante la evidencia de que los hijos no son más una metáfora de padres o madres. Si el imperio del sistema cultural de la escribalidad, con su culto a la semejanza y la metáfora, lo hizo posible, ese mundo de homogéneos no existe más.

Y esto no debe asombrarnos. Lo que ocurre es que nos habíamos habituado a pensar solo en la existencia de identidades semánticas y no logramos advertir la existencia de otro tipo de identidades: las identidades sintácticas. Las primeras, las identidades semánticas, implican reproducción social y cultural por semejanza; las segundas, las sintácticas, suponen producción social y cultural por contigüidad. Podríamos hablar, entonces también, de identidades metafóricas o metonímicas.

Ocurre que -lo hemos dicho- los sistemas culturales de la oralidad y la electronalidad tienden a privilegiar la metonimia como figura de sustitución. Por contraste con el sistema cultural de la escribalidad, que privilegiaba la metáfora. De lo que resulta que los hijos hoy no solo no quieran, sino simplemente no puedan -técnica y culturalmente hablando- ser metáforas de las figuras paterna o materna. Obviamente, nada de esto tiene que ver con los sentimientos filiales.

Mientras los jóvenes de ayer -y los grupos sociales- construían sus identidades a partir de un ser ideal posibilitado por la representación objetivada y por las figuras de semejanza metafórica propiciadas por dicho tipo de representación, los jóvenes de hoy -y los nuevos grupos sociales en configuración- construyen sus identidades en una cultura del hacer alimentada por el perspectivismo respecto a la representación, por un yo y un tú permanentemente en intercambio, por la atención sistemática a la contigüidad metonímica y -por ende- a los contextos.

Comprobamos, así, que las figuras retóricas -metáfora y metonimia en este caso- no son simples instrumentos de ornato o elocuencia lingüística. Constituyen patterns culturales con capacidad para construir imaginarios individuales y colectivos. Personas y grupos alimentados por la semejanza o la contigüidad. Codificadores de la homogeneidad o de la diferencia. En suma: metáfora y metonimia son fuente de identidades. De personas y países. 


\subsubsection{Del imperio de la subordinación a la yuxtaposición: papá, no quiero (o no puedo) ser como tú}

Quizá convenga que nos pongamos de acuerdo acerca del título de este parágrafo. Pues ciertamente no se trata de un llamado a la rebeldía. Se trata simplemente de llamar la atención -otra vez- sobre los cambios producidos ya por la electronalidad.

¿Por qué a los peruanos nos gusta tanto el chifa? No solo porque constituya en sí una comida cuyos sabores se emparientan con la nuestra. Se trata -también- de que la lógica del chifa es la yuxtaposición de platos, su simultaneidad. Como lo es la lógica de la comida criolla, cuya máxima expresión popular actual recibe precisamente el nombre de combinado.Y comida criolla y chifa se hermanan en la subyacencia de oralidades arraigadas.

La comida con paradigma afrancesado sabía de subordinaciones y sucesividades: entradas, platos principales, postres, entremeses, todo ello en la lógica de los denominados cursos lineales: un plato necesariamente antes que otro, excluyentes entre sí y servidos necesariamente en un determinado orden.

Los bufets modernos saben, más bien, de yuxtaposiciones. Nuevamente las simultaneidades se imponen sobre las sucesividades. Y todo ello no es obviamente casual.

Aun en una manifestación aparentemente fútil como la comida, es posible apreciar no solo la existencia de sintaxis o formas de combinación distintas, sino también las implicancias de ello en el arte culinario mismo y comprobar -icómo no!- el impacto que tienen las lógicas de las tecnologías de la información sobre el todo de la estructuración social.

Y ahora, por favor, les pedimos que regresen con nosotros a los años iniciales de la escuela. Para traer a la memoria lo que los libros escolares nos decían acerca de las oraciones coordinadas y las subordinadas. ¿Difícil recordarlo? Tal vez, pero seguramente el asunto les parecerá simple y lo evocarán: llamábamos oraciones coordinadas a aquellas que establecían relaciones entre palabras o grupos sintácticos del mismo nivel jerárquico. Y, como dice el Diccionario de la lengua española sobre estas oraciones, «de forma que ninguno de ellos (las palabras o los grupos sintácticos) esté subordinado al otro» (Real Academia Española 2003, las negritas son nuestras).

Y a propósito de las oraciones subordinadas, aprendimos también que estas establecían una relación entre dos oraciones, una de las cuales era dependiente de la otra. Volviendo al Diccionario de la lengua española: «Dicho de un elemento gramatical: Regir a otro de categoría diferente» (Real Academia Española 2003, las negritas son nuestras).

Cuando expresamos: «Vine, vi y vencí», ciertamente estamos ante un ejemplo de oración coordinada. Cuando decimos: «El comunicador que no sabe de negocios, no es hoy comunicador», nos adentramos en el mundo de las oraciones subordinadas. 
Pero no nos preocupemos. Este no es un tratado de gramática. De lo que se trata es de que entendamos que, así como metáfora y metonimia -y su privilegiamiento- constituían patterns culturales que alimentaban identidades, también el privilegiamiento de uno u otro tipo de oraciones es, a la vez, alimento y expresión de esas identidades.

El sistema cultural de la oralidad, es fácil comprobarlo, nos pone ante la preponderancia de las oraciones coordinadas. Temática y sintácticamente, la oralidad nos sitúa en el terreno de los denominados discursos $\sin$ fin. Es decir, cambiamos de un tema a otro y no subordinamos mayormente. Y esto mismo ocurre en el sistema cultural de la electronalidad.

Por contraste, en el sistema cultural de la escribalidad preponderan las subordinaciones. Temas y oraciones o ideas principales rigen otros elementos que orbitan semánticamente alrededor del subordinante.

En la medida en que la sintaxis para nosotros es -usando el término grado cero de Roland Barthes- el grado cero de la semántica, o sea principio formal de construcción de expresión y contenido, es claro que el privilegiamiento de la coordinación implica -como lo señalamos- un principio constructor no solo del lenguaje, sino de realidades, mentalidades e imaginarios.

No es casual que las construcciones coordinadas yuxtapuestas, vistas ya en una dimensión semiológica y atenta por lo tanto -como lo reclama Umberto Eco- a toda la cultura, generen productos culturales que combinan sintácticamente elementos de distinta naturaleza.

Allí están los muros incaicos conocedores de la coordinación yuxtapuesta, acá las construcciones hispánicas donde las columnas y vigas rigen el resto de las estructuras. En fin: allá las yuxtaposiciones medievales de los poderes feudales, mientras más acá las subordinantes monarquías absolutas y los mismísimos presidentes.

Muchos de los que estén leyendo este libro lo recordarán. Las casas -por ejemplo- tenían hasta no hace mucho lugares específicos para el desarrollo de actividades concretas. Cuando queríamos leer, estudiar o hacer las tareas escolares, allí estaba el escritorio; el dormitorio era el espacio dedicado únicamente al sueño nocturno; la familia se reunía a ingerir sus alimentos, forzosamente y en horarios determinados, en un lugar llamado comedor; las madres transitaban por todas las habitaciones, pero su hábitat «natural» era la cocina. Y el todopoderoso padre -por definición denominado hasta formalmente jefe del hogar- proveía el sustento económico. Los amigos no tan cercanos eran recibidos en la sala de la casa, donde también se reunía la familia toda en ocasiones especiales. Y siempre, casi siempre, había un lugar en la mesa del comedor no solo para congregar a la familia, sino también para los amigos más cercanos. 
Eran los tiempos del mundo de semejantes. Donde espacios y funciones estaban clasificados y especializados, siendo la escuela el vehículo que aseguraba la perpetuidad del modelo. De hecho, los dibujos de los libros escolares mostraban a los padres como ejes destacados y nucleares por encima de los hijos. A estos se les exigía obediencia y repetición. Los niños y jóvenes solo eran aún promesa de mercado autónomo, ya que los padres decidían por ellos. Era, pues, el mundo del imperio de la metáfora entre semejantes donde las existencias humanas solo podían saber de homogeneidad y su accionar era una mera sustitución del pattern referencial instituido socialmente. Evidentemente este era un mundo signado por la subordinación. Se actuaba únicamente semejando lo que la metáfora idealizada prescribía.

La distribución espacial de las casas lo decía. Sala y comedor, según fuese el caso, eran los elementos nucleares y privilegiados. Era imposible pensar en combinar un jean con un saco de vestir (aun cuando fuese sport), porque el saco formal subordinaba ya al resto de la vestimenta. Las comidas tenían un orden secuencial inexorable no solo porque desayuno, almuerzo, lonche y comida constituían un orden natural con fijación horaria, sino porque la entrada era siempre eso, una entrada a la que seguía necesariamente la -para muchosaborrecida sopa. El seguro apetecido plato de fondo debía esperar.

Si lo miramos bien, todo esto era reflejo del orden secuencial y clasificatorio impuesto por la cultura escribal. Del monopolio del libro como única tecnología de la información. Porque los libros empiezan y terminan, están divididos en capítulos especializados, exigen una lectura secuencial y constituyeron por tiempo referentes inmodificables y sacralizados. La verdad, la universalidad, la homogeneidad.

De pronto, la diversidad aparece como un valor. De pronto, los seres humanos dejan de ser simples consumidores -a través de la lectura de libros- de instrucciones ajenas. De pronto, los humanos recordamos que también éramos emisores y capaces por tanto de trazar caminos diversos. Paradójicamente, la llamada aldea global-vertebrada por la tecnología de la información de la electronalidad- no nos hizo a todos iguales (como muchos temían), sino más bien hizo saltar en pedazos el establishment ideológico de la homogeneidad para abrir las puertas a voces propias y singulares. Reapareció -como en tiempos de la oralidad- el prosumidor. La gente dejó de ser solo consumidora y readquirió su humano papel de emisora.

La electronalidad ha propiciado lo que un lingüista como García Bardón llamaría efecto de neutralización. Si bien sintácticamente el español prevé el uso de oraciones tanto coordinadas como subordinadas, internet, Facebook y Twitter -entre otros- privilegian las coordinaciones sobre las subordinaciones. Es decir, han neutralizado el uso de estas últimas. Acudimos poco a ellas y cuando lo hacemos creamos problemas cognitivos en los receptores. Lo dice la investigación científica. 
Las coordinadas -particularmente las yuxtapuestas- signan el lenguaje electronal. Y constituyen configurante y configurado de una nueva lógica que regula la propia lógica del hecho social y cultural. ¿Acaso las organizaciones empresariales no han abandonado ya la idea de los gerentes centrales todopoderosos y subordinantes en aras de la yuxtaposición de equipos de trabajo que velan específicamente por productos? ¿Acaso los nuevos núcleos familiares que se constituyen lo hacen sobre la base del contrato institucionalizado subordinado al denominado «jefe de familia»? ¿No hay por cierto una profunda crisis política en los Estados que pretenden centralizar poderes y servicios? ¿Acaso los hasta ayer inmodificables organismos internacionales -cuya voz subordinaba la del resto- no compiten ya con la yuxtaposición de países que trazan alianzas estratégicas ad hoc según sus propios intereses?

Y lo constatamos lógicamente también hoy en las comidas. No solo han variado los espacios donde se come y los horarios de la ingesta alimentaria. Se ha producido una profunda modificación de la lógica de preparación y consumo de los alimentos. Allí donde la lógica subordinante y escribal, cuya máxima expresión es la comida francesa, nos imponía la inevitable secuencia de los courses y del plato principal subordinante de todo lo demás, hoy asistimos -para desesperación de muchos maîtres aun en restaurantes reputados- a la inorgánica creatividad del consumidor. Que no vacila en destruir secuencia y subordinación.

Durante mucho tiempo, los que nos creímos asimilados a la escribalidad en el Perú sonreíamos ante un plato de tallarines bañados por una salsa de huancaína y probablemente algún huevo frito adyacente. Mirábamos hasta con desdén a quienes mezclaban lo dulce con lo salado en un solo plato. ¡Arroz con mango! sigue siendo una expresión -aun hoy en día- para aludir a algo que nos parece una mezcla intolerable. Todas estas miradas ejercidas desde la lógica de una cultura que imaginamos inmodificable.

Sin embargo, hoy vemos con naturalidad que en los modernos bufets -en unos más que en otros- se yuxtaponen en un solo plato entradas con platos principales. Entradas con entradas. Platos principales con platos principales. Hasta lo dulce con lo salado. Y nada de eso nos parece extraño ya.

Los patios de comida de los modernos malls comerciales se saturan de «combos». Yuxtaposiciones, entonces. Tal vez el plato popular más demandado sea el denominado aeropuerto. Una combinación de varias comidas. Más yuxtaposición.

Y es que con el advenimiento de las nuevas tecnologías de la información -particularmente internet- no solo ha reaparecido el prosumidor, que exige voz, decisión y creatividad en todo orden de cosas (desde la comida y el modo de vestir, pasando por la recodificación de los espacios de su vivienda, hasta las exigencias de nuevas instituciones sociales), sino que -y esto nos parece fundamental- estamos pasando de una lógica de la subordinación a una lógica de la yuxtaposición. En la que se encuentran culturas orales y electronales. 
A diferencia de muchos países, la poca penetración de la escribalidad en el Perú hizo a las mayorías poco afectas a la homogeneidad masificante y a la lógica de la subordinación. La pervivencia de una fuerte cultura oral mantuvo vivas la diversidad y la yuxtaposición.

Y he aquí que la posmodernidad vuelve los ojos a lo diverso y a lo yuxtapuesto. Porque esa es la lógica electronal. Y he aquí que la pervivencia de diversidad y yuxtaposición en nuestra comida dejan de ser una debilidad para convertirse en una fortaleza. Una envidiable oportunidad cultural para la afirmación de identidades.

Es claro que las gastronomías vertebradas por la lógica del ello subjetivado, de la yuxtaposición y de la contigüidad respetan más -no podía ser de otra manera- la propia etimología de la palabra compañero. Que significaba compartir el pan. De allí que la ritualidad del acto de comer en el Perú no solo pase por la ingesta de alimentos, o que sea una ritualidad vacía o acaso inhumana, sino que más bien sea un acto de compartir, de departir, de hacer de la comida una ocasión de amistad. Frente al silencio que muchas veces signa los espacios dominados por las lógicas subordinadas, las gastronomías yuxtapuestas saben más de la voz humana, del comentario y de la risa misma.

Gastón Acurio -desde su quehacer- ha tocado, pues, una fortaleza cultural que sustenta el éxito que viene alcanzando la gastronomía peruana. Entre nosotros y en el mundo. Porque al poner en valor nuestra comida tal vez nos haya hecho posar los ojos en lógicas que -más allá de la comida- tienen el poder de afianzar nuestra identidad.

Durante mucho tiempo el mundo oficial escribal anduvo cuestionando el asunto de nuestra identidad nacional como si esta fuese inexistente. Buscándola casi siempre considerándonos como una metáfora empobrecida del norte desarrollado. Algunos indagaron hasta por un inexistente inca, concebido como un rey subordinante. Este mismo mundo oficial fue el que se preguntó: «¿Cuándo se jodió el Perú?», siguiendo una expresión del escritor Mario Vargas Llosa en una de sus novelas. Lamentablemente, esta expresión podría nacer de pensar en la «pobreza espiritual» de nuestra cultura oral.

Pero he aquí que la electronalidad pone en valor lógicas y fortalezas que por siglos alimentaron una identidad silente. Solo ignota para la mirada de quienes no quisieron ver. Pues bien, el éxito de la gastronomía peruana -sobre el cual hemos venido hablando- no solo ha sido posible porque coincide con la lógica de la electronalidad. Sino porque establece una relación de continuidad entre fortalezas del pasado y del futuro.

Es claro que el éxito de la gastronomía y su poder identitario no hubiesen sido posibles sin la movilidad social y económica ocurrida en los últimos años en el Perú. Cuyo factor acelerador ha sido el feliz encuentro entre oralidad y electronalidad. 
Tal vez tuvo que ser el comer y la comida -elementos altamente simbólicos, pero finalmente rebeldes a ideologías totalitarias y fundamentalistas- el signo convocante para empezar a sentirnos partícipes de una comunidad, lo que -está demostrado- es posible si de veras confiamos y creemos en que nuestra tarea no es evangelizar a nuestros nativos en las ideologías que nos son caras, aunque signifique una perversa vuelta al pasado inmediato de la subordinación.

\subsection{Algunos primeros planos}

\subsubsection{La cultura del celular}

Es imposible que usted no lo haya vivido ya: ha concertado una cita en un café, la persona que espera no llega. De pronto, la voz de esa persona anuncia -a través del celular- su arribo inminente.

«Estoy llegando!», le deben haber dicho. Y usted perdonará el retraso, se sentirá hasta reconfortado, saboreará otro café. Aun sospechando (o sabiendo) que la persona que espera seguramente esté saliendo recién de su casa. 0 , tal vez, todavía esté en la ducha.

El móvil o celular, entonces, pareciese un cómplice de un rasgo de nuestra cultura contemporánea: la impuntualidad aceptada. En el fondo, la buena mentira.

Y lo mismo ocurre con los bien intencionados padres que entregan a sus hijos -cada vez a edad más temprana- un celular.

«¡Para mantenernos en contacto, hijo! ¡En cualquier momento, me llamas!». Y, sí, ocurren seguramente las llamadas. Aun cuando todos sepamos que, a pesar de que resuenen cerca las voces, las personas están distantes. Aun cuando sepamos que padre o hijo probablemente no estén donde lo anuncian. A pesar de que, tal vez inconscientemente, al entregar el celular al hijo estaremos creando distancias familiares con otra buena mentira «cómplicemente» aceptada: la proximidad permanente.

Podríamos, en fin, tratar de seguir caracterizando los efectos del celular en nuestras vidas. De cómo los enamorados están también cada vez más cerca, pero más lejos; de cómo competimos con las brillantes pantallas de los móviles cuando conversamos -o creemos hacerlo- con alguien. Podríamos, en suma, hacer un listado de males.

También podríamos hacer alusión a un rasgo más de esta cultura del celular. El habernos habituado a mirar el mundo -y a creer encontrar su sentido y significado- únicamente mirando el formato de la pantalla destellar. Ya la televisión nos había entrenado en esta mirada recortada; el celular ha intensificado este recorte de nuestras capacidades de mirar y leer el entorno-mundo real en su conjunto. 
Sin embargo, no caben dudas sobre las virtudes de este aparatito. Miles de personas han optimizado su trabajo gracias al contacto permanente. A la ubicuidad fácil y disponible. Y no hablamos solo de las ventajas de un smartphone, sino del modesto móvil «chancho» que permite al gasfitero o al jardinero un servicio delivery al paso de la demanda inmediata.

Y podríamos, más bien, con justicia, decir que las voces distantes transmiten muchas, muchas veces, afectos verdaderos y oportunos.

Voces que son, así, caricias para gentes -todas- cada vez más requeridas de la voz del otro diciéndonos: «Aquí estoy y te quiero».

\subsubsection{Infidelidad y el «choque y fuga»}

Cuando se hace un análisis lingüístico de frecuencia léxica y semántica en el discurso político, las palabras sostenibilidad e institucionalidad ocupan los primeros lugares.

Ambas constituyen ya un lugar común en el discurso de los analistas. Y, a pesar de ser palabras multisilábicas y por eso difíciles, aparecen con menor frecuencia -pero aparecen- en el decir de los actores políticos mismos.

Y ciertamente ambas palabras y aquello a lo que se refieren son ausencias constatables en nuestra frágil democracia. Allí está la inoperancia de un Estado insostenible para recordárnoslo; allí está la poca independencia de poderes, sustento de una democracia declarada; allí, los tránsfugas de todos los días.

No parecen, pues, nuestras organizaciones políticas ni nuestras instituciones llamadas «democráticas» existir bajo el signo de la institucionalidad. Y de esta ausencia deriva la poca fe en su sustentabilidad.

«Por mi mejoría mi casa dejaría...» decía ayer una vieja expresión popular. Y ahora, de pronto, nos vamos quedando sin «productos de bandera» en la televisión, la radio, la prensa escrita y hasta en la propia opinología oficial. Hoy las voces identificatorias de ayer migran con extrema facilidad.

Los jóvenes ingresan a un trabajo pensando ya en el otro. Los juramentos de amor «hasta que la muerte nos separe» no conocen tampoco de institucionalidad ni de sostenibilidad. Las adhesiones a nobles causas y cruzadas saben también de duraciones efímeras. Los enamoramientos no pasan tampoco de simples clics transitorios. Los trabajos son todos, casi sin excepción, instantáneas que no duran ya más de dos años. El Estado - ¡cómo no admitirlo!- no tiene adherentes permanentes. Las naciones, en fin, se diluyen en intereses acaso realizables en otras naciones. 
La vida nos va poniendo, entonces, ante la evidencia de que la institucionalidad y la sustentabilidad parecen ya «especies en extinción» que no son categorías sine qua non de las democracias. Pareciésemos más bien transitar por los senderos de democracias sin instituciones.

Un personaje farandulero en el Perú acuñó la frase «choque y fuga» para caracterizar las relaciones de pareja de hoy. Con los ejemplos que hemos dado, podríamos extender el término a otras esferas de los contratos individuales y colectivos.

¿No será, acaso, que la cultura de la instantaneidad y del discurso sin fin de la electronalidad viene ya signando nuestras interacciones? ¿No será que la velocidad y la ubicuidad electronales nos impiden ser fieles a la pareja, a la familia, al trabajo, a la causa noble (o innoble), a la ideología, al propio Estado?

Los comunicadores de verdad lo saben. Posicionamiento y fidelidad hacia los productos son exigencias del mercado. Hoy más que nunca, pues estamos ante un público objetivo «por naturaleza» infiel.

¿Podremos lograr institucionalidad y sustentabilidad con viejas recetas o parches a un Estado desfasado y por eso decrépito e ineficiente?

Solo tres palabras garantizan la interiorización y la permanencia de los signos: predicatividad, gratificación y economía. En ese orden.

Predicatividad significa que los signos deben decir realmente algo sobre las cosas; gratificación supone que los signos tengan la capacidad de satisfacer expectativas de la gente; y economía alude a que los receptores perciban una relación costo/beneficio ventajosa.

Reforma del Estado, entonces; no vueltas a tiempos idos. Requerimos valentía para preguntarnos si las viejas instituciones que asumimos como piedras angulares de la democracia son hoy viables. ¿Es solo un asunto de «humor» circunstancial, por ejemplo, la animadversión de la gente por la institución llamada Congreso, o es más bien testimonio y evidencia de una institución percibida como caduca?

El ciudadano-consumidor (hoy también productor y, así, nunca más solo receptor pasivo) está signado por una provechosa infidelidad. Esa que obliga a tener que ganar su amor y adhesión todos los días. Esa que obliga a que el Estado nunca tome distancia -y menos se olvide- de sus usuarios.

Electronalidad y globalización nos sitúan ante la verdad del «choque y fuga». ¿Nos animaremos a una reforma del Estado atenta de veras a la predicatividad, la gratificación y la economía? ¿Nos animaremos a eliminar -sí, eliminar- instituciones anacrónicas y viejas utopías? ¿Nos animaremos, en fin, a una tercerización efectiva del Estado -en todos sus niveles- para en serio incluir, tener un Estado eficiente y así institucionalizar y sostener formas de gobierno estables? 


\subsection{3 ¿Por qué los publicistas, junto con los poetas, habrían sido excluidos de «la república» de Platón?}

Recordamos para el lector -brevemente- que Platón expulsó de la república a los poetas. Los expulsó del mundo ideal. Y es que los poetas, en aquellos tiempos, adherían a la palabra hablada, y esta era inconveniente, peligrosa y subversiva respecto al mundo de verdades que pretendía configurar Platón a través de la palabra escrita.

Los publicistas también habrían sido arrojados por Platón. Y aún lo son por un mundo oficial construido unilateralmente sobre el privilegiamiento del pensamiento intelectual. Todavía hoy lo percibimos: quien no reconoce en un logotipo un proceso de alta abstracción porque se cree que a esta abstracción solo se llega por la palabra escrita, está desconociendo hechos y realidades por miopía o ceguera intelectual. Aun cuando esta le permita trazar acaso sesudas reflexiones sobre la importancia de la publicidad.

Dos pecados graves han cometido y cometen los publicistas en referencia a la red de verdades sobre cómo son y cómo no son las cosas construidas sobre el pensamiento intelectual. A ese mundo que -lo decíamos- propicia la esquizofrenia entre la Academia y la vida.

El primer pecado fue adherir a la persuasión. Adherir, entonces, al mundo de la retórica. Y persuasión y retórica también habían sido excluidas del mundo ideal platónico. Y, ¡cómo no!, retórica y persuasión eran armas de la palabra hablada, subversivas respecto a aquel mundo de la palabra escrita que se pretendía configurar de modo excluyente.

Un segundo pecado de los publicistas -pecado más moderno, pero igualmente imperdonable- fue aquel de adherir a la imagen como instrumento eficaz de comunicación en un mundo construido excluyentemente con la palabra escrita. Es el pecado de reivindicar el pensamiento visual. Educarnos, entonces, en que nuestras identidades y relaciones no solo se construyen con esa palabra excluyente, sino también con imágenes.

Pecado mayor este de construir una retórica de la imagen y de pretender, por añadidura, persuadir a través de ella.

En la tradición de Occidente, la Biblia hebrea significa la desaparición de Dios como referente físico. Las encarnaciones físicas de la divinidad fueron reemplazadas por la palabra. Como lo recuerda Arnold Hauser, ya Eusebio -en el siglo III- decía que la representación de Cristo es idolatría y contraria a la escritura. Como también lo subrayó Asterio de Amasea: «No copies a Cristo: ya le basta con la humillación de la Encarnación a la cual se sometió voluntariamente por nosotros; antes bien lleva en tu alma espiritualmente el verbo incorpóreo» (Hauser 1978: 153). 
¿Y qué decían la palabra y las escrituras? Que el hombre había sido creado a imagen y semejanza de Dios. El hombre era así una metáfora de Dios: la metáfora, como sabemos, es una figura de sustitución basada en la semejanza. Pero ¿cómo era físicamente ese referente llamado Dios al cual éramos semejantes? Imposible saberlo. Porque las imágenes habían sido proscritas. En el corazón del texto sagrado se institucionalizaba la metáfora como arjé o principio cultural original del todo. Metáfora que, al carecer sin embargo de referente físico, posibilitaba a los detentadores del poder dibujar a Dios de acuerdo con sus intereses. Y así entendemos mejor a los iconoclastas. Que luchaban contra la reproducción física de la divinidad. En el fondo, luchaban a favor de un texto escrito que debía ser sagrado y que había sido capaz de construir la gran metáfora fundacional de una cultura, suprimiendo la visualización del referente. Las imágenes se tornaron así subversivas respecto a la palabra escrita.

Y ahora comprendemos mejor el desdén intelectual por el quehacer publicitario. Doblemente pecaminoso: por acudir a la proscrita retórica y a la persuasión, y por hacerlo a la imagen.

Cuando hoy reaparecen en los universos simbólicos de los hombres las imágenes como principio hacedor y cuando constatamos el anatema hacia la imagen -piénsese en el desprecio hacia los ideogramas de niños y jóvenes que utilizan emoticones en su comunicación escrita-, ¿no será que sin saberlo estamos reproduciendo paradigmas religiosos en sociedades que pretendemos construir en la laicidad? ¿No será que nos resistimos a abandonar sociedades cerradas -construidas excluyentemente sobre la palabra y la palabra escrita y el texto finalmente sagrado e inmutable- por temor a adherir a sociedades realmente abiertas?

Por deformación profesional, hemos separado sintaxis de semántica. Hemos circunscrito la sintaxis a la forma no semántica. Cuando la sintaxis es el grado cero de la semántica. Principio de construcción. No solo de contenido. Y aquí nos encontramos con el diseño gráfico. Entendible como la sintaxis del espacio y también del tiempo. Que nos hace readvertir la presencia del pensamiento visual y el fin del monopolio mercantilista del pensamiento intelectual. Que obliga a los intelectuales a reconocer categorías hasta ayer desdeñadas.

La publicidad y el diseño gráfico nos pueden hacer vivir mejor. No solo porque sus promesas de ilusión nos permiten seguir siendo niños. Y creer en Papá Noel. Sino porque, con prescindencia de las inobjetables repercusiones de la publicidad sobre la actividad económica, la publicidad y el diseño gráfico nos reconfortan con la persuasión y con la imagen. La primera nos pone siempre en la necesidad de pensar en «el otro», no ya como semejante sino como distinto y diverso; la segunda -la imagen- nos restituye gran parte del precio que habíamos debido pagar por incorporarnos a la república de Platón: nos restituye el dominio del pensamiento sensorial. ¡Habíamos trabajado tanto tiempo con la mitad de nuestro cerebro, al adherir solo al pensamiento intelectual! ¡Y nos habíamos enriquecido -pero también empobrecido- tanto! 
Para poder amar, hay que comprender con inteligencia. Comprendamos los cambios culturales en los que estamos inmersos y de los cuales somos protagonistas. «Dicen que el tiempo cambia cosas, pero tiene que cambiarlas realmente usted», decía Andy Warhol. Siempre es tiempo de cambiar de paradigmas. 
Para poder revisar todo el contenido de esta edición, visite nuestra tienda virtual.

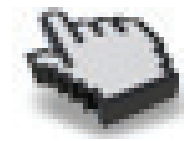

\section{$\boldsymbol{\varphi}$}

Juan Biondi · Eduardo Zapata

\section{Nómades electronales}

Lo que nos dicen las escrituras de los jovenes: habfa que echarse a andar nuevamente

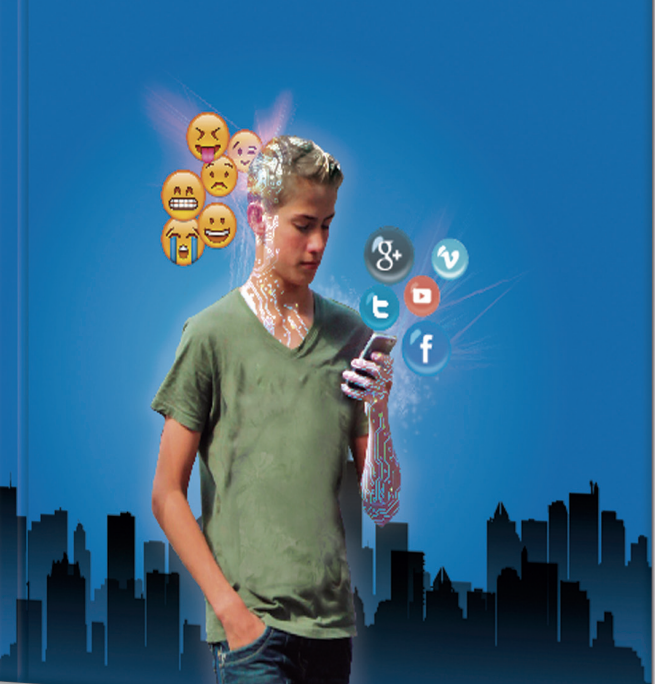

